Check for updates

Cite this: RSC Adv., 2017, 7, 50657

Received 16th September 2017 Accepted 23rd October 2017

DOI: 10.1039/c7ra10303d

rsc.li/rsc-advances

\section{On-site separation of $\mathrm{Cr}(\mathrm{VI})$ and $\mathrm{Cr}(\mathrm{III})$ in natural waters by parallel cartridge ion-exchange columns†}

\author{
Jia Zhang, ${ }^{a}$ Wei Guo, (D) *ab Qinghai Guo, ${ }^{\text {ac }}$ Lanlan Jin, ${ }^{\text {a }}$ Zhifu Liu ${ }^{a}$ \\ and Shenghong $\mathrm{Hu}$ (D) $^{\text {a }}$
}

A simple, fast, portable, and solvent-free method is developed for field separation of $\mathrm{Cr}(\mathrm{VI})$ and $\mathrm{Cr}(\mathrm{III})$ in natural waters. The method involves passing a water sample through parallel cation- and anion exchange resin cartridge columns at the field site. In a matter of seconds, all the $\mathrm{Cr}(\mathrm{III})$ is retained on the cation-exchange column and $\mathrm{Cr}(\mathrm{VI})$ passes to the effluent, while the $\mathrm{Cr}(\mathrm{VI})$ is quantitatively retained on the anion-exchange resin and $\mathrm{Cr}(\mathrm{III})$ passes to the effluent. The two collected solutions are preserved and determined later in the laboratory using inductively coupled plasma mass spectrometry (ICP-MS) or any other elemental analysis technique sufficiently sensitive to measure the $\mathrm{Cr}$ concentrations of interest. $\mathrm{Cr}(\mathrm{VI})$ ( or $\mathrm{Cr}(\mathrm{III})$ ) can be separated from $\mathrm{Cr}(\mathrm{III})$ (or $\mathrm{Cr}(\mathrm{VI})$ ) at the $\mathrm{pH}$ range 1-10 at $\mathrm{Cr}(\mathrm{III}) / \mathrm{Cr}(\mathrm{VI})$ ( $\mathrm{or} \mathrm{Cr}(\mathrm{VI}) / \mathrm{Cr}(\mathrm{III})$ ) concentration ratios as high as 10000 (or 500). The limits of detection for $\mathrm{Cr}(\mathrm{III})$ and $\mathrm{Cr}(\mathrm{VI})$ are 0.03 and $0.01 \mu \mathrm{g} \mathrm{L}^{-1}$, respectively. Repeatability expressed as relative standard deviation is determined to be $7.1 \%$ for $\mathrm{Cr}(\mathrm{VI})$ and 5.7\% for $\mathrm{Cr}(\mathrm{III})$, using a drinking water sample containing $1.14 \mu \mathrm{g} \mathrm{L}^{-1} \mathrm{Cr}(\mathrm{VI})$ and $0.72 \mu \mathrm{g} \mathrm{L}^{-1} \mathrm{Cr}(\mathrm{III})$. The parallel cartridge ion-exchange resin columns can be used continuously for 40 drinking water samples without any regeneration or cleaning procedure. The accuracy is validated by analysing $\mathrm{Cr}(\mathrm{III})$ and $\mathrm{Cr}(\mathrm{VI})$ in three water standard reference materials (GBW080257, GBW080403, and GBW080404). Furthermore, the proposed method is applied to the on-site separation of $\mathrm{Cr}(\mathrm{III})$ and $\mathrm{Cr}(\mathrm{VI})$ from natural waters.

\section{Introduction}

Chromium (Cr) present in the environment appears mainly as a result of human activities such as electroplating, leather tanning, metal finishing, and the textile industry. ${ }^{\mathbf{1 , 2}}$ The bioavailability and toxicity of $\mathrm{Cr}$ depend upon its chemical form; $\mathrm{Cr}$ (III) is a biologically important species that plays essential roles in the metabolic pathways of glucose and lipids as well as protein metabolism, whereas $\mathrm{Cr}(\mathrm{vI})$ is carcinogenic, mutagenic, and is implicated in stomach and skin cancers., $\mathrm{Cr}(\mathrm{vI})$ concentration limits for drinking water stipulated by the World Health Organization (WHO), the US Environmental Protection Agency (EPA), and the Chinese government are 50, 10 , and $6 \mu \mathrm{g} \mathrm{L}^{-1}$, respectively. ${ }^{5-7}$ The California EPA has gone as far as to set a public health goal for $\mathrm{Cr}(\mathrm{vI})$ in drinking water of

${ }^{a}$ State Key Laboratory of Biogeology and Environmental Geology, School of Earth Sciences, China University of Geosciences, Wuhan, 430074, PR China. E-mail: Wei. Guo@cug.edu.cn; qhguo2006@gmail.com

${ }^{b}$ Engineering Research Center of Nano-Geo Materials of Ministry of Education, China University of Geosciences, Wuhan, 430074, PR China

${ }^{\prime}$ School of Environmental Studies, China University of Geosciences, Wuhan, 430074, PR China

$\dagger$ Electronic supplementary information (ESI) available. See DOI: $10.1039 / \mathrm{c} 7 \mathrm{ra} 10303 \mathrm{~d}$
$0.02 \mu \mathrm{g} \mathrm{L^{-1 }}$ in order to protect the health of residents at a lifetime risk level of "one-in-a-million". ${ }^{6}$

The most commonly performed analytical strategy for $\mathrm{Cr}$ monitoring involves two steps: (1) collection of water samples at the field site followed by storage and transportation it to the laboratory, and (2) analysis using atomic spectrometry after separation by one of a number of online or offline separation approaches, such as solid-phase extraction, liquid-liquid extraction, cloud-point extraction, or co-precipitation. ${ }^{\mathbf{8 - 1 4}}$ However, accurate speciation of $\mathrm{Cr}$ in natural water bodies is difficult, mainly due to matrix complexity and the instability of Cr redox species during sample collection, transport, and analysis. ${ }^{15}$ For example, Meeravali et al. ${ }^{16}$ found that the concentration of $\mathrm{Cr}(\mathrm{III})$ increased by $135 \%$ and that of $\mathrm{Cr}(\mathrm{VI})$ decreased by $75 \%$ within $24 \mathrm{~h}$ when lake water samples were collected and stored at $4{ }^{\circ} \mathrm{C}$. This demonstrates that the concentrations of chemical species in particular redox states are inherently unstable in water and subject to change by re-equilibration upon reaction with other dissolved components. ${ }^{17}$ Thus, a method for $\mathrm{Cr}$ speciation that ensures that the final results reflect the original states of the $\mathrm{Cr}$ species is required.

Field speciation methods or techniques for immediate on-site separation (followed by laboratory analysis) could help prevent inter-conversion of $\mathrm{Cr}$ species and provide more reliable results. To this end, Yang et al. ${ }^{18}$ developed a fully automated portable 
analyser consisting of a micro-sequential injection lab-on-value system and a miniature USB2000 spectrophotometer for field speciation of $\mathrm{Cr}$. Based on the chromogenic reaction of $\mathrm{Cr}(\mathrm{vI})$ with diphenylcarbazide (DPC), the $\mathrm{Cr}(\mathrm{vI})$ content in an original sample and the total $\mathrm{Cr}$ after oxidation were quantified using a micro-column reactor containing bismuthate-immobilized silica. The feasibility of this method was validated using three wastewater samples. However, its relatively poor detection limit (5.6 $\mu \mathrm{g} \mathrm{L}^{-1}$ for $\mathrm{Cr}(\mathrm{vI})$ ) does not meet the requirements of most natural water samples $\left(0.1-10 \mu \mathrm{g} \mathrm{L}^{-1}\right.$ levels). Furthermore, a sensitive speciation method based on field separation with dispersive liquid-liquid micro-extraction (M-MM-DLLME) for sequential and simultaneous separation and pre-concentration of $\mathrm{Cr}(\mathrm{vI})$ and $\mathrm{Cr}(\mathrm{III})$ was developed by Kumar et al. ${ }^{16}$ The low volumes of the final extracted phase $(0.6 \mathrm{~mL}$ for $\mathrm{Cr}(\mathrm{VI})$ or $\mathrm{Cr}(\mathrm{III}))$ are easily transported to the laboratory at room temperature for quantification using electrothermal atomic absorption spectrometry (ETAAS). This on-site separation method does not require storage and transportation of samples at $4{ }^{\circ} \mathrm{C}$. However, the separation procedure is complicated and its application to real samples is difficult. ${ }^{16}$ Moreover, Romero et al. ${ }^{19}$ used multilayer grapheme membranes as the pre-concentration platform for selective absorption of $\mathrm{Cr}(\mathrm{vI})$ from natural waters followed by quantitation using a portable total reflection X-ray fluorescence spectroscopy apparatus. In addition, a field analysis method has been developed based on the separation of $\mathrm{Cr}(\mathrm{VI})$ and $\mathrm{Cr}(\mathrm{III}) \mathrm{using}$ two tandem small resin-loaded extraction disks and analysing them directly using diffuse reflectance spectroscopy (DRS). ${ }^{20}$ When the aqueous sample is pushed through the disks, the $\mathrm{Cr}(\mathrm{vI})$ is retained on the top anion-exchange disk and $\mathrm{Cr}$ (III) is extracted by the second cation-exchange disk. The concentration on each disk is several-hundred fold higher than that of the original sample. ${ }^{20}$ Although the detection capacity is limited by the DRS measuring method (sub-mg $\mathrm{L}^{-1}$ levels), this solvent-free and simple method introduced the possibility of field sampling and separation techniques for Cr species, avoiding the sampling and preservation operations needed when using centralized analytical techniques.

Consequently, this study describes a simple method for onsite separation of $\mathrm{Cr}(\mathrm{VI})$ and $\mathrm{Cr}(\mathrm{III})$ from natural waters using parallel cation- and anion-exchange column cartridges. The cation-exchange column retains $\mathrm{Cr}(\mathrm{III})$, while $\mathrm{Cr}(\mathrm{VI})$ passes through and is collected in the effluent. Conversely, the anionexchange column retains $\mathrm{Cr}(\mathrm{VI})$ and elutes the $\mathrm{Cr}(\mathrm{III})$. The final solutions are analysed later in a laboratory using inductively coupled plasma mass spectrometry (ICP-MS). The optimization of the technique, evaluation of its analytical performance, and its application to the determination of $\mathrm{Cr}(\mathrm{VI})$ and $\mathrm{Cr}(\mathrm{III})$ in natural and drinking water samples are described.

\section{Experimental}

\section{On-site separation assembly and procedure}

As shown in Fig. 1, the on-site assembly consists of a cation ionexchange column (SCX, $500 \mathrm{mg}, 55 \mu \mathrm{m}$ particle size, Phenomenex, USA), an anion ion-exchange column (SAX, $500 \mathrm{mg}, 55 \mu \mathrm{m}$ particle size, Phenomenex, USA), a disposable syringe ( $5 \mathrm{~mL})$,

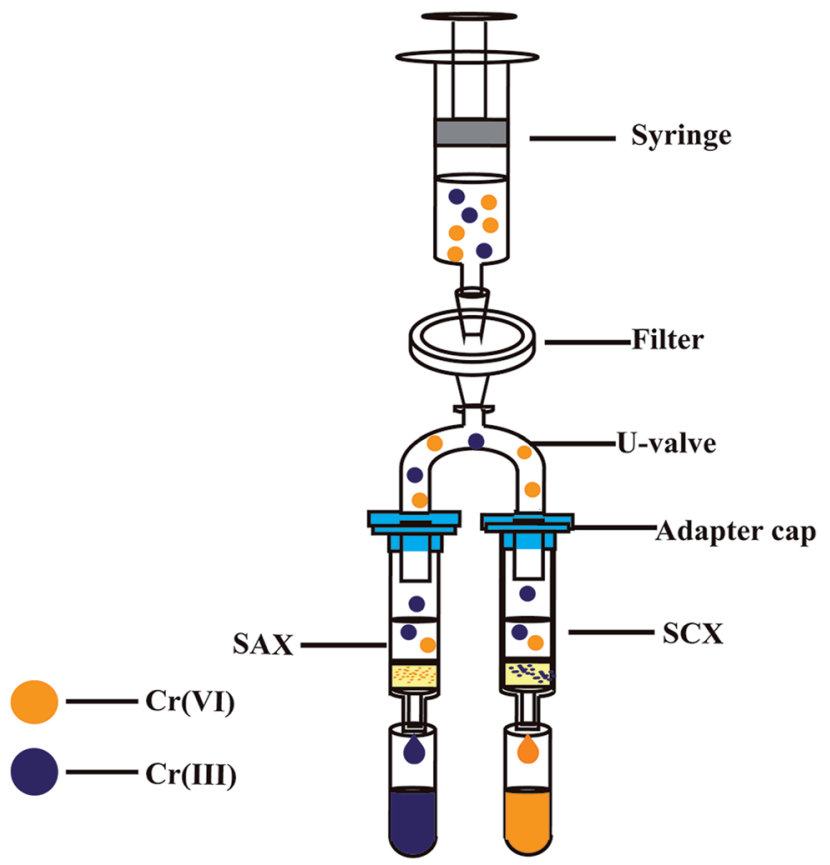

Fig. 1 Schematic of $\mathrm{Cr}(\mathrm{VI})$ and $\mathrm{Cr}$ (III) separation equipment. SCX: strong cation-exchange resin column $(500 \mathrm{mg}, 3 \mathrm{~mL})$, SAX: strong anionexchange resin column (500 mg, $3 \mathrm{~mL}$ ).

a syringe filter (cellulose acetate, $0.45 \mu \mathrm{m}$ ), a U-valve, a suitable adapter cap, and two centrifuge tubes $(5 \mathrm{~mL})$. The structures of the SCX and SAX resins are shown in Fig. S1. $\dagger$ Before use, the SCX and SAX resin columns were activated with $10 \% \mathrm{H}_{2} \mathrm{SO}_{4}$ for $3 \mathrm{~h}$ and $5 \% \mathrm{NaCl}$ for $4 \mathrm{~h}$, respectively. A $4.0 \mathrm{~mL}$ sample is aspirated into a disposable plastic syringe. After purging of all air, the sample is slowly forced through the filter and split into the SCX and SAX columns. In a matter of seconds, the Cr(III) is retained on the cation-exchange resin and $\mathrm{Cr}(\mathrm{vI})$ passes into the first centrifuge tube, meanwhile the $\mathrm{Cr}(\mathrm{vI})$ is retained on the anion-exchange resin and $\operatorname{Cr}(\mathrm{III})$ passes into the second centrifuge tube. The two collected solutions (each $2.0 \mathrm{~mL}$ ) are preserved and analysed later in the laboratory.

\section{Instrumentation, reagents, and standards}

A 7700x ICP-MS (Agilent, USA) with a collision reaction cell (CRC) was used for determining the separated solutions in the laboratory. Helium was introduced at an optimized flow rate of $4.0 \mathrm{~mL} \mathrm{~min}^{-1}$ into the CRC to remove the ions (i.e., ${ }^{40} \mathrm{Ar}^{12} \mathrm{C}^{+}$) that interfere with ${ }^{52} \mathrm{Cr}^{+}$determination. Ion chromatography (IC, DIONEX ICS-900, Thermo Fisher, USA) coupled with ICPMS (7700x) ${ }^{21}$ was used to certify the accuracy of the proposed method. ICP-optical emission spectrometry (ICP-OES, IRIS, Thermo Fisher, USA) was employed to check the matrix elements in the water samples. High-purity water (18.2 $\mathrm{M} \Omega \mathrm{cm}^{-1}$ ) used for the preparation of all the blanks, samples, and standards was obtained from a water purification system (Millipore, France). Analytical-grade $\mathrm{HNO}_{3}$ and $\mathrm{H}_{2} \mathrm{SO}_{4}$ were purchased from Alfa Aesar Ltd. (Tianjin, China). Standard solutions of $\operatorname{Cr}(\mathrm{III})$ and $\mathrm{Cr}(\mathrm{VI})$, single element stock solutions 
(including $\mathrm{K}, \mathrm{Na}, \mathrm{Ca}, \mathrm{Mg}, \mathrm{Fe}, \mathrm{Ba}$, and $\mathrm{Al}$ ), anion solutions (including $\mathrm{F}^{-}, \mathrm{Cl}^{-}, \mathrm{NO}_{3}{ }^{-}$, and $\mathrm{SO}_{4}{ }^{2-}$ ), and three water standard reference materials (SRMs, GBW080257, GBW080403, and GBW080404) were purchased from the National Institute of Metrology of China (NIMC, China).

\section{Results and discussion}

\section{Separation of $\operatorname{Cr}(\mathrm{vI})$ and $\operatorname{Cr}(\mathrm{III})$}

Owing to the opposite charges of $\mathrm{Cr}(\mathrm{III})$ and $\mathrm{Cr}(\mathrm{VI})$ species, cationic $\mathrm{Cr}(\mathrm{III})$ has a strong affinity for the cation-exchange resin, while anionic $\mathrm{Cr}(\mathrm{vI})$ passes into the effluent. Conversely, the anion-exchange resin quantitatively retains the anionic $\mathrm{Cr}$ (vI) species and completely elutes the Cr(III). The feasibility of this method was determined in an initial experiment, in which a mixed solution of $\mathrm{Cr}(\mathrm{III})$ and $\mathrm{Cr}(\mathrm{vI})\left(2.0 \mu \mathrm{g} \mathrm{\textrm {L } ^ { - 1 }}\right.$ for each species in $1 \% \mathrm{HNO}_{3}$ solution) was directly injected to the parallelcartridge ion-exchange columns and the $\operatorname{Cr}(\mathrm{III})$ and $\operatorname{Cr}(\mathrm{VI})$ levels in the effluents were determined by ICP-MS to be 1.94 and $1.97 \mu \mathrm{g} \mathrm{L}^{-1}$, respectively. The results of IC-ICP-MS analysis confirmed that only $\mathrm{Cr}(\mathrm{vI})$ species were present in the SCXs effluent and only $\mathrm{Cr}$ (III) species was present in the SAXs effluent (Fig. 2). The prerequisite for separation by ion-exchange resin is that all the targets are present in their ionic states, such as $\mathrm{Cr}(\mathrm{vI})$ as negatively-charged hydrogen chromate $\left(\mathrm{HCrO}_{4}{ }^{-}\right)$or chromate $\left(\mathrm{CrO}_{4}{ }^{2-}\right)$ and $\mathrm{Cr}(\mathrm{III})$ as positively-charged $\mathrm{Cr}^{3+}, \mathrm{CrOH}^{2+}$, or $\mathrm{Cr}(\mathrm{OH})^{2+} \cdot{ }^{15}$ The $\mathrm{Cr}$ ionic state is strongly dependent on the solution $\mathrm{pH}$ value ${ }^{22}$ thus, the effect of sample $\mathrm{pH}$ on the separation of $\mathrm{Cr}(\mathrm{III})$ and $\mathrm{Cr}(\mathrm{VI})$ was investigated. Fig. 3 shows that the recoveries of $\mathrm{Cr}(\mathrm{III})$ and $\mathrm{Cr}(\mathrm{VI})$ are both in the range $90-100 \%$ for solution $\mathrm{pH}$ values between 1 and 10. A high $\mathrm{pH}(>11)$ leads to poor recovery of $\mathrm{Cr}(\mathrm{III})$. Therefore, the sample $\mathrm{pH}$ need not be pre-adjusted by acid or base, because this wide range of $\mathrm{pH}$ (1-10) is common to almost all natural waters. ${ }^{23}$

\section{Interfering effects}

In the ion-exchange resin method, interference ions can compete with the target ions $(\mathrm{Cr}(\mathrm{VI})$ or $\mathrm{Cr}(\mathrm{III})$ ) for absorption to

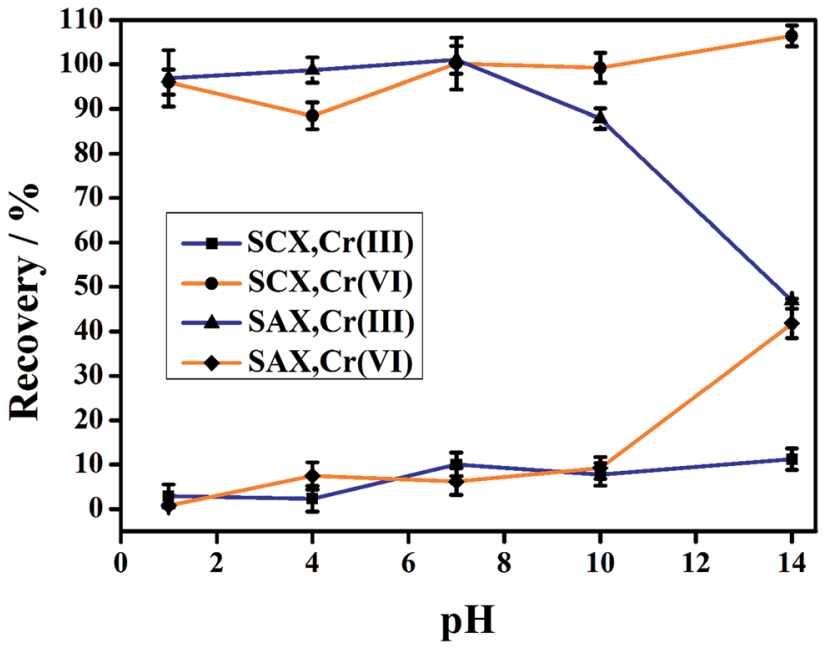

Fig. 3 Effect of sample $\mathrm{pH}$ on the separation of $\mathrm{Cr}(\mathrm{VI})$ and $\mathrm{Cr}(\mathrm{III})$ using the parallel cartridge ion-exchange columns $\left(10 \mu \mathrm{g} \mathrm{L}^{-1}\right.$ for each $\mathrm{Cr}$ species).

the resin surface or direct oxidization or reduction. Thus, in order to assess potential interference, the tolerability of the method frequently encountered ions was studied by spiking solutions containing $\mathrm{Cr}(\mathrm{VI})$ and $\mathrm{Cr}(\mathrm{III})$ at $20 \mu \mathrm{g} \mathrm{\textrm {L } ^ { - 1 }}$ each. Table 1 shows that $\mathrm{Cr}$ species (other than the target species) having concentrations at least 500 times than that of the target $\mathrm{Cr}$ species can be separated. The recovery of $\mathrm{Cr}(\mathrm{III})$ is $107 \%$ in the presence of $10 \mathrm{mg} \mathrm{L}^{-1} \mathrm{CrO}_{4}{ }^{2-}$ and that of $\mathrm{Cr}(\mathrm{vI})$ is $90.6 \%$ in the presence of $10 \mathrm{mg} \mathrm{L}^{-1} \mathrm{Cr}^{3+}$. Nearly all the investigated ions have a negligible effect on the recovery of $\mathrm{Cr}$ (III) by the SAX column. Except for in the presence of $\mathrm{Fe}^{2+}$ and $\mathrm{Fe}^{3+}$, the recoveries of $\mathrm{Cr}(\mathrm{vI})$ range from 89.4 to $106 \%$ when the ratios of concentration of foreign species to that of the target ion are in the range 5000100000 (Table 1). However, this method appears to provide accurate $\mathrm{Cr}(\mathrm{vI})$ recovery $(85.5 \%)$ in the presence of $\mathrm{Fe}^{2+}$ at $\sim 250$ fold concentration $\left(5.0 \mathrm{mg} \mathrm{\textrm {L } ^ { - 1 }} \mathrm{Fe}^{2+}\right.$ ), beyond which the recoveries decrease dramatically with increasing $\mathrm{Fe}^{2+}$ content. This

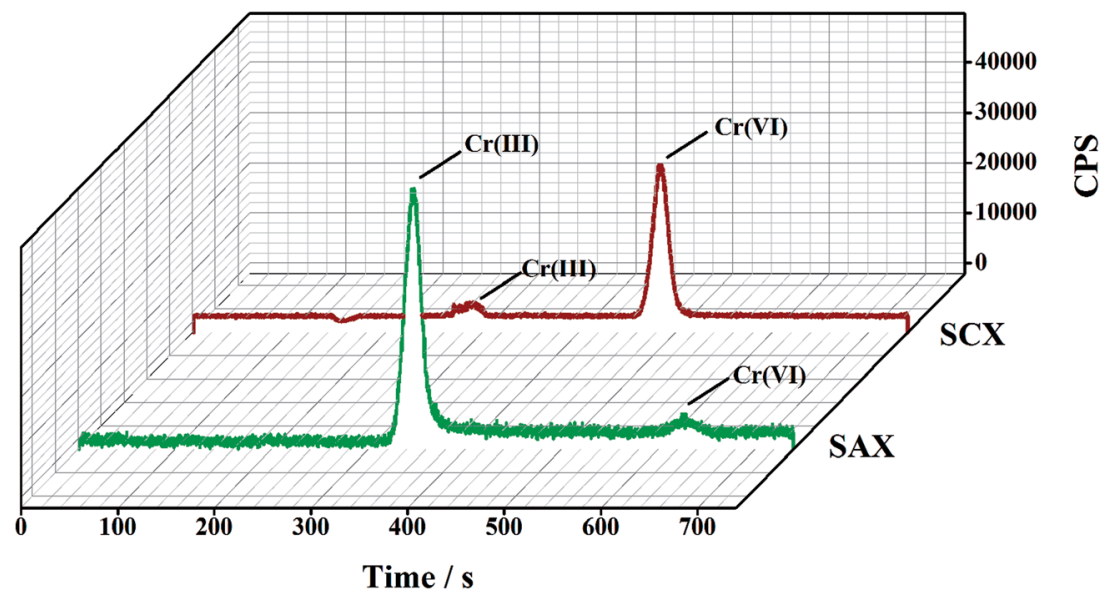

Fig. 2 A typical IC-ICP-MS spectrum for the two solutions collected after separation by the parallel cartridge ion-exchange columns $\left(2.0 \mu \mathrm{g} \mathrm{L}^{-1}\right.$ for each $\mathrm{Cr}$ species). 
Table 1 Tolerance concentration ratios for foreign ions on the separation of $\mathrm{Cr}$ species, $n=3$

\begin{tabular}{llll}
\hline & & \multicolumn{2}{l}{ Recovery (\%) } \\
\cline { 3 - 4 } Foreign species & Concentration & Cr(III) & $\mathrm{Cr}(\mathrm{vI})$ \\
\hline $\mathrm{Cr}^{3+}$ & 500 & - & $90.6 \pm 0.6$ \\
$\mathrm{CrO}^{2-}$ & 500 & $107 \pm 1$ & - \\
$\mathrm{K}^{+}, \mathrm{Na}^{+}, \mathrm{Ca}^{2+}, \mathrm{Mg}^{2+a}$ & 20000 & $95.6 \pm 0.1$ & $106 \pm 1$ \\
$\mathrm{Fe}^{2+}$ & 100 & $99.1 \pm 0.6$ & $95.5 \pm 0.1$ \\
$\mathrm{Fe}^{2+}$ & 250 & $99 \pm 1$ & $85.5 \pm 2.5$ \\
$\mathrm{Fe}^{2+}$ & 50000 & $97.5 \pm 0.9$ & $1.2 \pm 0.6$ \\
$\mathrm{Fe}^{3+}$ & 100 & $99.3 \pm 0.7$ & $92.8 \pm 1.9$ \\
$\mathrm{Fe}^{3+}$ & 250 & $99.2 \pm 1.0$ & $86.7 \pm 3.0$ \\
$\mathrm{Fe}^{3+}$ & 50000 & $97.8 \pm 3.2$ & $0.4 \pm 0.5$ \\
$\mathrm{Al}^{3+}$ & 50000 & $99.2 \pm 0.3$ & $89.4 \pm 1.3$ \\
$\mathrm{Ba}^{2+}$ & 50000 & $99.3 \pm 0.1$ & $95.1 \pm 0.3$ \\
$\mathrm{~F}^{-}, \mathrm{Cl}^{-}, \mathrm{SO}_{4}{ }^{2-}, \mathrm{NO}_{3}{ }^{-b}$ & 100000 & $88.4 \pm 2.0$ & $97.2 \pm 1.3$
\end{tabular}

${ }^{a}$ The concentration of each ion was $100 \mathrm{mg} \mathrm{L}^{-1} .{ }^{b}$ The concentration of each ion was $500 \mathrm{mg} \mathrm{L}^{-1}$.

may be due to the reduction of $\mathrm{Cr}(\mathrm{vI})$ to $\mathrm{Cr}(\mathrm{III})$ by $\mathrm{Fe}^{2+}$ and subsequent co-precipitation with (or adsorbing of) Cr. Although the tolerance limits for $\mathrm{Fe}^{2+}$ and $\mathrm{Fe}^{3+}$ are relatively low, their concentrations in common water samples does not exceed $1.0 \mathrm{mg} \mathrm{L}^{-1}$ (Table S1†). In addition, the nature water contains negatively charged colloids, including humic substances, kaolin, hydrated silica and their mixtures with hydrated iron(III) oxide, ${ }^{24}$ which may sorb $\mathrm{Cr}(\mathrm{III})$ and be partly retained on the anion-exchange resins. ${ }^{25}$ However, the concentration of these $\mathrm{Cr}(\mathrm{III})$ associated with negatively charged colloids is less than $10 \%$ of $\mathrm{Cr}(\mathrm{vI})$ in natural waters. ${ }^{26}$ In fact, no oxidation or reduction occurs (i.e., interconversion of $\mathrm{Cr}$ species) during this separation because no acid/base or solvent are required to adjust sample $\mathrm{pH}$ or elute the target, respectively.

\section{Analytical performance}

The limits of detection (LODs) for $\mathrm{Cr}(\mathrm{VI})$ and $\mathrm{Cr}(\mathrm{III})$, define as three times the relative deviation of 11 consecutive measurements of the blank solutions, are 0.01 and $0.03 \mu \mathrm{g} \mathrm{L} \mathrm{L}^{-1}$, respectively. Table 2 shows that the LODs of the proposed method ars better than those of other reported field separation methods $^{18-20}$ and are comparable with the IC-ICP-MS results $\left(0.04 \mu \mathrm{g} \mathrm{L}^{-1}\right.$ for $\mathrm{Cr}(\mathrm{vI})$ and $0.01 \mu \mathrm{g} \mathrm{L}{ }^{-1}$ for $\left.\mathrm{Cr}(\mathrm{III})\right) .{ }^{27}$ The relative standard deviation (RSDs) for $\mathrm{Cr}(\mathrm{VI})$ and $\mathrm{Cr}(\mathrm{III})$, calculate from the relative deviation of three consecutive measurements of a drinking water (containing $1.14 \mu \mathrm{g} \mathrm{L} \mathrm{L}^{-1} \mathrm{Cr}(\mathrm{vI})$ and $0.72 \mu \mathrm{g} \mathrm{L} \mathrm{L}^{-1}$ $\mathrm{Cr}(\mathrm{III})$ ). The accuracy of the proposed method was first validated by analysing three water SRMs. The results for GBW080257, GBW080403, and GBW080404 are 0.16, 4.44, and $88.83 \mu \mathrm{g} \mathrm{L} \mathrm{L}^{-1}$, respectively, for $\mathrm{Cr}(\mathrm{vI})$ and $0.45,0.74,9.49 \mu \mathrm{g} \mathrm{L}^{-1}$, respectively, for $\mathrm{Cr}(\mathrm{III})$, which are in good agreement with the reference values measured by IC-ICP-MS. Although no certified values are available for $\mathrm{Cr}(\mathrm{vI})$, no differences are observed between the values detected by this method and those obtained by IC-ICPMS for $\mathrm{Cr}(\mathrm{VI})$ and $\mathrm{Cr}(\mathrm{III})$ (Table 3). In addition, for a drinking water sample spiked with $\mathrm{Cr}(\mathrm{VI})$ and $\mathrm{Cr}(\mathrm{III})$ at different levels, the

Table 2 Comparison of the current method with other reported field speciation methods for $\mathrm{Cr}(\mathrm{III})$ and $\mathrm{Cr}(\mathrm{VI})$

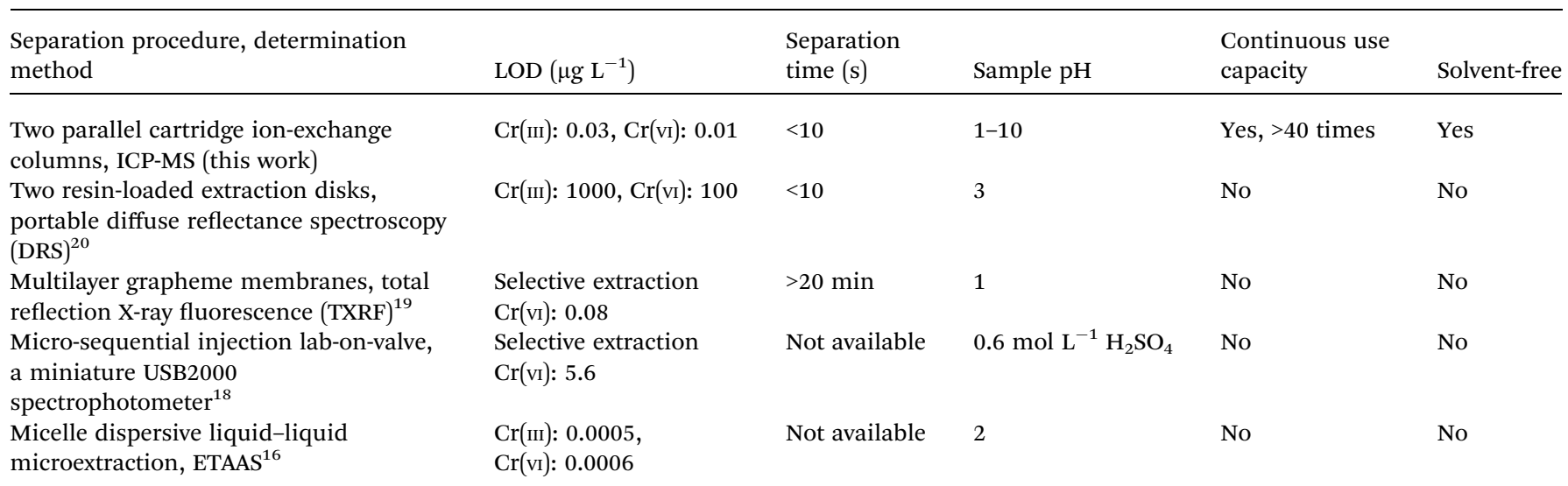

Table 3 Analytical results for $\mathrm{Cr}$ species in SRMs $\left(\mu \mathrm{L} \mathrm{L}^{-1}\right), n=3$

\begin{tabular}{|c|c|c|c|c|c|}
\hline $\mathrm{SRMs}^{a}$ & $\mathrm{Cr}(\mathrm{III})$ & $\operatorname{Cr}(\mathrm{vI})$ & $\mathrm{Cr}(\mathrm{III})$ & $\operatorname{Cr}(\mathrm{vI})$ & $\begin{array}{l}\text { Certified value } \\
\text { total } \mathrm{Cr}\end{array}$ \\
\hline GBW (E)080404 & $0.74 \pm 0.03$ & $4.44 \pm 0.01$ & $0.62 \pm 0.09$ & $4.45 \pm 0.08$ & 5.00 \\
\hline GBW (E)080257 & $9.49 \pm 1.18$ & $88.83 \pm 0.13$ & $11.59 \pm 0.07$ & $89.02 \pm 0.26$ & 100.00 \\
\hline
\end{tabular}

${ }^{a}$ Dilution of 1000-fold for the original SRM. 
recoveries for the $\mathrm{Cr}$ species in the ranges $98.3-108.5 \%$ and 99.3-115.2\%, respectively (Table 4).

To check the column capacity of this method, a groundwater sample was passed continuously through the ion-exchange columns and the two effluents were collected (Fig. 4). Without any regeneration or cleaning steps, the values obtained for the

Table 4 Recoveries (\%) of $\mathrm{Cr}(\mathrm{VI})$ and $\mathrm{Cr}(\mathrm{III})$ in drinking water samples, $n=3$

\begin{tabular}{llllr}
\hline Species & $\begin{array}{l}\text { Tested values } \\
\left(\mu \mathrm{g} \mathrm{L}^{-1}\right)\end{array}$ & $\begin{array}{l}\text { Spiked values } \\
\left(\mu \mathrm{g} \mathrm{L}^{-1}\right)\end{array}$ & $\begin{array}{l}\text { Found values } \\
\left(\mu \mathrm{g} \mathrm{L}^{-1}\right)\end{array}$ & \multicolumn{1}{c}{$\begin{array}{l}\text { Recovery } \\
(\%)\end{array}$} \\
\hline $\mathrm{Cr}(\mathrm{VI})$ & $1.14 \pm 0.07$ & 0.94 & $2.16 \pm 0.12$ & 108.5 \\
& & 4.42 & $5.49 \pm 0.31$ & 98.5 \\
& & 9.52 & $10.5 \pm 0.77$ & 98.3 \\
$\mathrm{Cr}(\mathrm{III})$ & $0.72 \pm 0.03$ & 1 & $1.76 \pm 0.11$ & 105.1 \\
& & 4.43 & $5.15 \pm 0.24$ & 99.3 \\
& & 10.35 & $11.18 \pm 0.54$ & 115.2
\end{tabular}

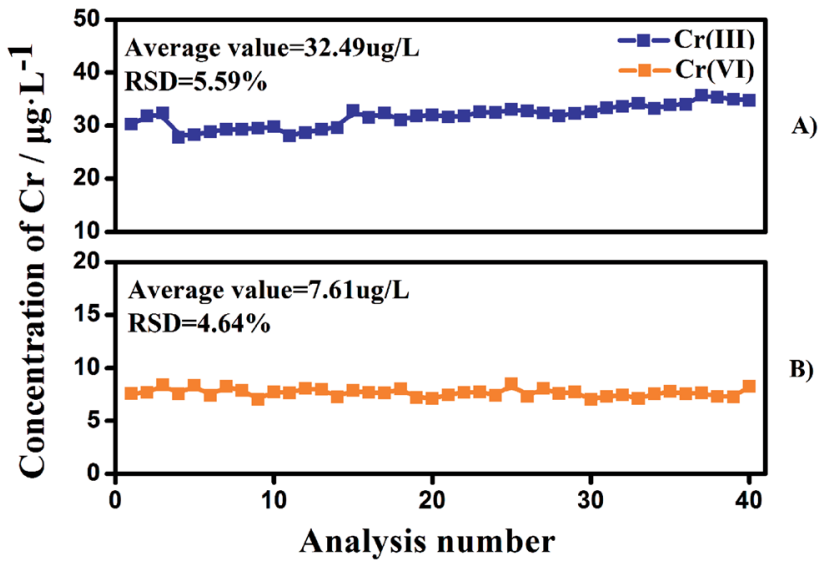

Fig. 4 The stability of the proposed method for $\mathrm{Cr}(\mathrm{VI})$ and $\mathrm{Cr}(\mathrm{III})$ separation without any regeneration or cleaning steps. Ground water was used in this experiment.

Table 5 Speciation of $\mathrm{Cr}$ in natural water samples $\left(\mu \mathrm{g} \mathrm{L}^{-1}\right), n=3$

\begin{tabular}{|c|c|c|c|}
\hline \multirow[b]{2}{*}{ Samples } & \multicolumn{2}{|l|}{ This study } & \multirow{2}{*}{$\frac{\text { Reported value }^{28}}{\mathrm{Cr}(\mathrm{vI})}$} \\
\hline & $\mathrm{Cr}(\mathrm{III})$ & $\mathrm{Cr}(\mathrm{vI})$ & \\
\hline S1 & N.D. ${ }^{a}$ & $0.60 \pm 0.07$ & $-^{b}$ \\
\hline S2 & $0.28 \pm 0.03$ & $0.98 \pm 0.11$ & 8 \\
\hline S3 & $1.01 \pm 0.03$ & $2.46 \pm 0.21$ & 8 \\
\hline S4 & $0.9 \pm 0.02$ & $2.92 \pm 0.14$ & 6 \\
\hline S5 & N.D. & $0.80 \pm 0.08$ & - \\
\hline S6 & N.D. & $0.95 \pm 0.13$ & - \\
\hline S7 & $0.07 \pm 0.02$ & $1.12 \pm 0.12$ & - \\
\hline S8 & $0.10 \pm 0.02$ & $0.17 \pm 0.01$ & - \\
\hline S9 & $0.67 \pm 0.06$ & $4.25 \pm 0.13$ & - \\
\hline S10 & $0.33 \pm 0.04$ & $1.90 \pm 0.17$ & 6 \\
\hline S11 & N.D. & $0.95 \pm 0.12$ & 174 \\
\hline S12 & N.D. & $2.74 \pm 0.26$ & 113 \\
\hline
\end{tabular}

Cr species for the $40^{\text {th }}$ injection $\left(7.6 \mu \mathrm{g} \mathrm{L}^{-1}\right.$ for $\mathrm{Cr}(\mathrm{vI})$ and $32.6 \mu \mathrm{g} \mathrm{L}{ }^{-1}$ for $\left.\mathrm{Cr}(\mathrm{III})\right)$ are the same as those obtained for the first injection $\left(7.5 \mu \mathrm{g} \mathrm{L}^{-1}\right.$ for $\mathrm{Cr}(\mathrm{VI})$ and $31.2 \mu \mathrm{g} \mathrm{\textrm {L } ^ { - 1 }}$ for $\left.\mathrm{Cr}(\mathrm{III})\right)$. Thus, the capacity of the resin column (500 mg) allows at least 40 samplings without any cleaning step for typical natural waters. Larger amounts of cation and anion exchange resins are recommended for water samples with high concentrations of dissolved organic carbon and/or having high ionic strength.

\section{Application to the natural water samples}

This on-site separation method was used to monitor the $\mathrm{Cr}(\mathrm{vI})$ and $\mathrm{Cr}$ (III) concentrations of 12 natural water samples, which are collected from lakes of neighboring a chrome salt factory in Huangshi (Fig. S2 $\dagger$ ). Table 5 shows that the $\mathrm{Cr}(\mathrm{vI})$ contents range from 0.17 to $4.25 \mu \mathrm{g} \mathrm{L}^{-1}$ and the $\mathrm{Cr}(\mathrm{III})$ contents range from $<$ LOD to $1.01 \mu \mathrm{g} \mathrm{L}^{-1}$. Previous data ${ }^{28}$ (Table 5) reveal that the concentrations of $\mathrm{Cr}(\mathrm{vI})$ at the same sites almost a decade ago were 3- to 180-times to those measured recently.

\section{Conclusions}

Very fast $(<10 \mathrm{~s})$ on-site separation of $\mathrm{Cr}(\mathrm{VI})$ and $\mathrm{Cr}(\mathrm{III})$ was achieved by passing a water sample through parallel ionexchange resin column cartridges. Anionic $\mathrm{Cr}(\mathrm{vI})$ was obtained from the effluent of the cation-exchange column, while $\mathrm{Cr}$ (III) was collected from the effluent of the anion-exchange column. The amounts of each Cr species can be obtained later by ICP-MS (or any other elemental analysis instrument with sufficient sensitivity) in the laboratory. This solvent-free method avoids inter-conversion of the $\mathrm{Cr}$ species and provides a routine protocol for the determination of $\mathrm{Cr}(\mathrm{VI})$ and $\mathrm{Cr}(\mathrm{III})$ in natural waters.

\section{Conflicts of interest}

There are no conflicts to declare.

\section{Acknowledgements}

This work was supported by the China Scholarship Council, the National Natural Science Foundation of China (No. 41521001, 41773013, 41572335, and 41772370), the Fundamental Research Funds for the Central Universities, China University of Geosciences (Wuhan) (No. CUG170102), the Research Funds for Engineering Research Center of Nano-Geo Materials of Ministry of Education (NGM2016KF007), and the Research Program of State Key Laboratory of Biogeology and Environmental Geology of China.

\section{References}

1 M. Chebeir and H. Liu, Environ. Sci. Technol., 2016, 50, 701710.

2 C. Pan, L. D. Troyer, J. G. Catalano and D. E. Giammar, Environ. Sci. Technol., 2016, 50, 13502-13510.

3 K. Pytlakowska, J. Anal. At. Spectrom., 2016, 31, 968-974. 
4 U.S. Environmental Protection Agency, Toxicological review of hexavalent chromium, Washington, DC, 2015, http:// www.epa.gov/iris/toxreviews/0144tr.pdf.

5 World Health Organization, Guidelines for Drinking Water Quality, WHO Press, World Health Organization, Geneva, 4th edn, 2011.

6 http://www.ct.gov/dph/lib/dph/drinking_water/pdf/Hexavalent_ Chromium_in_Drinking_Water.pdf.

7 People's Republic of China Ministry of Health, Standards for drinking water quality, GB 5749-2006, revised in 2006.

8 S. Cuello, J. Entwisle, J. Benning, C. Liu, S. Coburn, K. G. McAdam, J. Braybrook and H. Goenaga-Infante, J. Anal. At. Spectrom., 2016, 31, 1818-1829.

9 I. Gaubeur, M. A. Aguirre, N. Kovachev, M. Hidalgo and A. Canals, J. Anal. At. Spectrom., 2015, 30, 2541-2547.

10 F. Hernandez, P. Jitaru, F. Gormant, L. Noel and T. Guerin, Food Chem., 2018, 240, 183-188.

11 N. Unceta, M. Astorkia, Z. Abrego, A. Gomez-Caballero, M. A. Goicolea and R. J. Barrio, Talanta, 2016, 154, 255-262.

12 B. Markiewicz, I. Komorowicz and A. Sajnog, Talanta, 2015, 132, 814-828.

13 K. Pyrzynska, TrAC, Trends Anal. Chem., 2012, 32, 100-112.

14 K. Pyrzynska, Int. J. Environ. Anal. Chem., 2012, 92, 12621275.

15 J. W. Ball and R. B. McCleskey, Talanta, 2003, 61, 305-313.
16 N. N. Meeravali, K. Madhavi and S. J. Kumar, J. Anal. At. Spectrom., 2016, 31, 1582-1589.

17 S. Comber and M. Gardner, J. Environ. Monit., 2003, 5, 410413.

18 M. Yang, J.-X. Li and J.-H. Wang, Talanta, 2007, 72, 17101716.

19 V. Romero, I. Costas-Mora, I. Lavilla and C. Bendicho, RSC $A d v .$, 2016, 6, 669-676.

20 S. A. Steiner, M. D. Porter and J. S. Fritz, J. Chromatogr. A, 2006, 1118, 62-67.

21 H. Cui, W. Guo, L. L. Jin, Q. H. Guo and S. H. Hu, Anal. Methods, 2017, 9, 1307-1312.

22 F. Seby, S. Charles, M. Gagean, H. Garraud and O. F. X. Donard, J. Anal. At. Spectrom., 2003, 18, 1386-1390.

23 B. Markiewicz, I. Komorowicz, A. Sajnog, M. Belter and D. Baralkiewicz, Talanta, 2015, 132, 814-828.

24 M. Hiraide, M. Ishii and A. Mizuike, Anal. Sci., 1988, 4, 605609.

25 P. A. Sule and J. D. Ingle Jr, Anal. Chim. Acta, 1996, 326, 8593.

26 M. Hiraide and A. Mizuike, Fresenius' Z. Anal. Chem., 1989, 335, 924-926.

27 E. Leese, J. Morton, P. H. E. Gardiner and V. A. Carolan, J. Anal. At. Spectrom., 2016, 31, 924-933.

28 B.-J. Hu, T. Ma, C.-F. Liu and L. Li, Saf. Environ. Eng., 2007, 14, 20-23. 